\title{
Çocukluk Çağında Çarpıntı Yakınması ile Başvuran Hastalarda Ritim Holter Monitorizasyon Sonuçlarının Değerlendirilmesi
}

\section{Evaluation of the results of rhythm holter monitorization in children with palpitation in childhood}

\author{
Gamze KARAMANLI, Ayşe Esin KIBAR GÜL², Emine AZAK², Hazım Alper GÜRSU², \\ İbrahim İlker ÇETiN²
}

${ }^{1}$ Sağlık Bilimleri Üniversitesi, Ankara Çocuk Sağlığı ve Hastalıkları Hematoloji Onkoloji SUAM, Çocuk sağlığı ve Hastalıkları Kliniği, Ankara, Türkiye

${ }^{2}$ Sağlık Bilimleri Üniversitesi, Ankara Çocuk Sağlığı ve Hastalıkları Hematoloji Onkoloji SUAM, Çocuk Kardiyoloji Kliniği, Ankara, Türkiye

\section{Öz}

Amaç: Çalışmamızda çarpıntı yakınmasıyla başvuran çocuk hastalarda 24 saatlik ritim holter monitorizasyon (HM) endikasyonları gözden geçirilmiştir. Bu çalşmanın amacı, holterde görülen ritim bozukluklarının tür ve sıklığının saptanması, holterin tanı ve tedavideki yeri vurgulanmaktır.

Gereç ve Yöntemler: Ocak 2016-Ocak 2018 tarihleri arasında kliniğimize çarpıntı yakınması ile başvuran, 4-17 yaş arası (ortalama yaş $13.1 \pm 3.4$ ) 364 hastanın 383 adet HM sonuçları geriye dönük değerlendirildi.

Bulgular: Hastaların \%11.5'inde $(n=42)$ elektrokardiyografide $(E K G)$, \%33'ünde $(n=120)$ holterde disritmi bulundu. Holter endikasyonları içinde; \%88.5'ini EKG incelemesi normal olup nedeni belli olmayan çarpıntı ve/veya disritmik semptomları devam edenler hastalar oluşturmaktaydı. Hastaların \%56.9'unda $(n=206)$ izole çarpıntı ve \%43.4'ünde $(n=158)$ diğer eşlik eden yakınmalar; bunlar içinde de en sık göğüs ağrısı (\%24.2) ve senkop (\%10.4) kaydedildi. Hem EKG'de hem de HM'da disritmi olan hastalarda (\%36.1), EKG'si normal olup HM'da disritmi olan hastalara (\%15.5) göre ciddi disritmi saptanma oranı anlamlı yüksek saptandı ( $p=0.023)$. Holterde en sık saptanan disritmiler \%10.1 ( $\mathrm{n}=37$ ) ile supraventriküler ekstrasistol (SVE) ve \%9 $(n=33)$ ile ventriküler ekstrasistol (VES)'di. Bu iki ritim bozukluğunun birlikte görülme oranı ise \%2.4 $(n=9)$ bulundu. Holter monitorizasyondaki ritim bozuklukları yaş gruplarına göre incelendiğinde $\leq 10$ yaş SVE sıklı̆ı \%3, VES sıklı̆ı \%1.4 iken, $\geq 11$ yaş bu oranlar sırasıyla \%7.1 ve \%7.7'di. Yaş gruplarına göre HM'da disritmi dağlımında istatiksel anlamlı fark saptanmadı ( $p>0.05$ ).

Sonuç: Çalışmamızda, çocuk kardiyoloji kliniğine çarpıntı şikayeti ile başvuran hastaların yaklaşık üçte birinde disritmi saptanmış ve bunların da \%7.1'inde $(n=26)$ ciddi disritmiler olduğu belirlenmiştir Anormal EKG'nin holter kaydının tanıya katkısını arttırdığı saptanmıştır. Ayrıca EKG'si normal olan hastalarımızda da holterde disritmi kaydedilmesi ritim bozukluklarının saptanmasında EKG'nin yetersiz kalabildiğini ve HM'nun özellikle pediatrik yaş grubunda yararlı bir tanı aracı olabileceğini düşünmekteyiz.

Anahtar Sözcükler: Çarpıntı, Çocuklar, Holter monitorizasyonu, Kardiyak disritmi

\section{ABSTRACT}

Objective: In our study, we evaluated 24-hour rhythm holter monitarization (HM) indications in pediatric patients presenting with palpitations. The aim of this study was to determine the type and frequency of rhythm disorders seen in holter, and to emphasize the place of holter in diagnosis and treatment.

(1)

KARAMANLI G: 0000-0001-9858-2210 KIBAR GÜL AE : 0000-0001-7833-7701 AZAKE : :0000-0002-7841-1331 GÜRSU HA : :0000-0002-0707-2678 CETIN II : : :0000-0001-9480-8278
Çıkar Çatıșması / Conflict of Interest: Tüm yazarlar adına, sorumlu yazar çıkar çatıșması olmadığını belirtir.

Etik Kurul Onayı / Ethics Committee Approval: Bu çalıșmada ulusal ve uluslararası etik kurallara uyulmuştur. Bu çalıșma için Ankara Çocuk Sağlığı ve Hastalıkları Hematoloji Onkoloji SUAM, Klinik Araștırmalar Etik Kurul'ndan 2018/094 onay alınmıştır. Kayıt sırasında veliler tarafından araştırmaya katılım için bilgilendirilmiș bir onay imzalanmıștir.

Yazarların katkısı / Contribution of the Authors: KARAMANLI G: Hasta takibinde sorumluluk almak, ilgili biyolojik malzemelerin toplanması, veri yönetimi ve raporlama, deneylerin yürütülmesi, Sonuçların mantıksal olarak Yorumlanması ve sonuçlandırılması, KiBAR GÜL AE: Sonuçlara ulaşmak için planlama/metodoloj belirleme, Araștırma/çalıșmanın sorumluluğunu üstlenmek, ilerlemenin seyrini denetlemek, Sonuç̧ların mantıksal olarak Yorumlanması ve sonuçlandırılması, AZAK E: Çalıșma için gerekli literatür taramasında sorumluluk almak, Yazım ve dilbilgisi dısıında bilimsel olarak gönderilmeden önce makaleyi gözden geçirme, GÜRSU HA: Araștırma/çalıșmanın sorumluluğunu üstlenmek, ilerlemenin seyrini denetlemek, CETiN ii: Araștırma ve/veya makalenin hipotezini veya fikrin oluşturan, Sonuçlara ulaşmak için planlama/metodoloji belirleme.

Atıf yazım şekli / How to cite : Karamanlı G, Kibar Gül AE, Azak E, Gürsu HA, Çetin ï. Çocukluk Çağında Çarpıntı Yakınması Ile Başvuranlarda Ritim Holter Monitorizasyon Sonuçlarının Değerlendirilmesi. Türkiye Çocuk Hast Derg 2020;14:318-324.
Yazıșma Adresi / Correspondence Address:

Ayşe Esin KiBAR GÜL

Sağllk Bilimleri Üniversitesi, Ankara Çocuk Sağlığı ve Hastallıkarı Hematoloji Onkoloji SUAM, Çocuk Kardiyoloji

Kliniği, Ankara, Türkiye

E-posta: dreseresin@yahoo.com
Geliş tarihi / Received : 08.02.2019 Kabul tarihi / Accepted : 29.03.2019 Elektronik yayın tarihi : 09.08.2019 Online published

DOI: 10.12956/tchd.524017 
Material and Methods: $383 \mathrm{HM}$ results of 364 patients in the age of 4 and 17 (average age $13.1 \pm 3.4$ ) who applied to the pediatric cardiology outpatient clinic with complaint of palpitation between January 2016 and January 2018 were evaluated retrospectively.

Results: In $11.5 \%$ of patients ( $n=42)$ dysrhythmia was detected in $E C G$, in $33 \%$ of them $(n=120)$ dysrhythmia was detected in Holter. If we look at the Holter indications of the patients $88.5 \%$ had normal ECG examination, but ongoing unspecified of palpitations and dysrhythmic. $56.9 \%$ of patients $(n=206)$ had complaint of isolated palpitation, $43.4 \%$ of patients $(n=158)$ had other coexisting complaints such as chest pain (24.2\%) and syncope (10.4\%). In patients with dysrhythmias in both ECG and HM (36.1\%), ECG was normal and the rate of severe dysrhythmia was found to be significantly higher in patients with arrhythmia (15.5\%) than in patients with $\mathrm{HM}(\mathrm{p}=0.023)$. The most common rhythm disorders in holter results were $10.1 \%(n=37)$ SVE and 9\% ( $n=33)$ VES. Coincidence of two rhythm disorders was $2.4 \%(n=9)$. If the rhythm disorders in HM were examined according to age groups, in the age $\leq 10$; the frequency of SVE was \%3, the frequency of VES was $1.4 \%$. On the other hand in patients of age $\geq 11$, the frequency of SVE was $7.1 \%$, the frequency of VES was $7.7 \%$. According to age group there was no statistically significant difference in dysrhythmia distribution in ECG and HM ( $p>0.05$ ).

Conclusion: In this study, dysrhythmia was detected about one third of patients who applied to the pediatric cardiology outpatient clinic with the complaint of palpitation and serious dysrhythmia was detected in $7.1 \%$ of them $(n=26)$. Abnormal ECG was found to increase the contribution of holter recording to the diagnosis. In addition, in patients with normal ECG, the recording of dysrhythmia in the holter, ECG may be inadequate in detecting rhythm disorders and therefore, HM may be a useful diagnostic tool especially in pediatric age group.

Key Words: Cardiac dysrhythmia, Children, Dysrhythmia, Holter monitoring, Palpitation

\section{GiRiș}

Önemli kardiyak disritmilerin en yaygın semptomu çarpıntıdır. Bununla birlikte çocukluk çağında çarpıntı yakınmasıyla başvuran olgular artmakta ve son yllarda önemli bir sorun olarak karşımıza çıkmaktadır. Elektokardiyografi (EKG) ile yapılan değerlendirmede, çocuklarda disritmilerin aralıkı ortaya çıkması, hastanın semptomsuz dönemde olması ve ritmin kısa bir dönemi için bilgi edinilmesi nedeniyle ritim bozuklukları saptanmayabilir (1).

Holter monitorizasyonu; rutin muayene sırasında düzensiz ritmin fark edilmesi ve/veya disritmik semptomların (çarpıntı, presenkop, senkop vb.) varlığı, kalp hastalığı ve anormal EKG'si olan hastalarda önerilmektedir (2). Erişkin disritmilerin tanısında HM yaygın olarak kullanılmasına rağmen pediatrik yaş grubunda çocuklarda holter ile ilgili çalışmalar da sınırıdır (1,3-6). Kardiyak ritmin gün boyu izlendiği holter incelenmesi ile taşikardiler, bradikardiler, hasta sinüs sendromu ve diğer semptomatik disritmiler tanınabilmektedir. Yirmidört saatlik ritim HM disritmilerin tanı ve izleminde en özgül ve en duyarı tanı aracıdır (3). Çarpıntıda HM'nun tanısal başarısı çalışmalarda \%33-35 bulunmuştur (2).

Bu çalışmada çarpıntı yakınmasıyla başvuran çocuk hastalarda 24 saatlik HM endikasyonları gözden geçirilmiş, holterde görülen ritim bozukluklarının tür ve sıkıı̆ının saptanması, holterin tanı ve tedavideki yeri vurgulanmak istenmiştir.

\section{GEREÇ ve YÖNTEMLER}

Ocak 2016 - Ocak 2018 tarihleri arasında kliniğimize çarpıntı yakınması ile başvuran 364 hastaya yapılan toplam 383 adet 24 saatlik HM kayıtları geriye dönük olarak incelendi. Holter kaydı için DMS 300-3A Digital Holter Recorder (model no:65597, Germany) cihazı kullanıldı. Çalışma için hastanemiz etik kurulunun onayı alındı (2018/094). Hastaların yaş ve cinsiyet dağlımı, demografik özellikleri, çarpıntıya eşlik eden semptomlar, tanımlanmış ek sistemik hastalıkları, aile öyküleri, fizik muayene ve laboratuvar bulguları, 12 derivasyonlu EKG kayıtları (Nihon Konden ECG-1350,Cardiofax, Japan), ekokardiyografi (EKO) incelemesi ve HM sonuçları ile disritmi saptanan hastaların bulguları ve disritmi ile ilgili yapılan ek tetkikler (efor EKG, elektrofizyolojik inceleme) kaydedildi.

Taranan semptomlar; izole çarpıntı (Grup 1) ve/veya çarpıntıya eșlik eden diğer semptomlar (Grup 2) olmak üzere iki ana gruba ayrıldı. Grup 2'de alt gruplar içinde; grup 2a: çarpıntı ve göğüs ağrısı, grup 2b: çarpıntı ve baş dönmesi \pm senkop \pm eforla ilişkili senkop ve grup 2c: çarpıntı ve yorgunluk \pm çabuk yorulma \pm nefes darlığı şeklinde tanımlandı ve disritmi yönünden ayrıntıı değerlendirildi.

Yirmidört saatlik kayıt süresi boyunca temel ritim, kayıt sırasında semptomların belgelenmesi, ortalama kalp hızı (HR), minimum $H R$, maksimum HR ve ventriküler ektopi, supraventriküler ektopi vb eşlik eden disritmilerin varlığı kaydedildi. Holterdeki disritmi tanıları ACC / AHA yönergeleri ile tanımlandı (7). Holterde saptanan disritmilerin tipleri; supraventriküler ektopi (SVE), ventriküler ektopi (VES), izole ve/veya bigemine VES, SVE+VES, supraventriküler taşikardi (SVT), nodal escape atımlar, multifokal atriyal taşikardi, atriyal ektopik taşikardi, ventriküler taşkardi (VT), atriyal fibrilasyon, atriyal flatter, sinüs taşikardisi, sinüs bradikardisi, sinus pause, aşağı atriyal ritim, nodal ritim, değișken atriyal pacemaker, WPW, hasta sinüs sendromu, uzun QT sendromu ve AV bloklar kaydedildi. Holter analizinde disritmiler; ciddi/klinik açıdan önemli disritmi ve klinik açıdan önemsiz/selim disritmiler olarak iki grupta değerlendirildi (8). Holterde SVT (supraventriküler hız > $150 \mathrm{atım} / \mathrm{dk}$ ), multifokal ya da bigemine VES, ventriküler taşikardi atağı (VT, ventriküler hız,> 120 atım / dk), \%10 ve üstü SVE ve VES, Wenckebach olmayan, 2. derece kalp bloğu veya 3 . derece kalp bloğu, $>3$ sn sinüs duraklaması, uzun QT ve preeksitasyon sendromları ile ilişkili taşikardi, hasta sinüs sendromu saptanması ciddi/klinik açıdan önemli disritmi olarak tanımlandı.

\section{İstatistiksel Analizler}

İstatistiksel analizler ve hesaplamalar için SPSS Statistics 15.0 Version for Windows Evaluation programı kullanıldı. İstatistiksel anlamlılık düzeyi $\mathrm{p}<0.05$ olarak kabul edildi. Çalışmada yer 
alan hastaların sayısal değerlerinin normal dağılıma uygunluğu Shapiro Wilks testi ile incelendi. Kategorik değişkenler arasında farkllıkların incelenmesinde Pearson Ki kare (Pearson ChiSquare), Yates Ki kare (Continuity Correction) ve Fisher exact testten (Fisher's Exact Test) uygun olan yöntem sonuçları verildi. Holterde disritmi saptama açısından belirleyici faktörleri bulmak için lojistik regresyon analizi yapıldı.

\section{BULGULAR}

Çalışmaya alınan hastalar 4-17 yaş arasında (ortalama yaş 13.1 \pm 3.4 yıl), 243'ü (\%66.8) kız ve 121'i (\%33.2) erkekti. Hastaların yaş grubuna göre dağılımına baktığımızda; \%75.8'i (n=276) $\geq 11$ yaș ve \%24.2'si ( $n=88) 10$ yaș ve altı saptandı. Hastaların \%56.9'unda izole çarpıntı, \%43.4'ünde çarpıntıya eşlik eden yakınmaları mevcuttu. Çarpıntıya \%24.2'sinde göğüs ağrısı, \%10.4'ünde senkop, \%8'inde baş dönmesi, \%6.6'sında nefes darlığı, \%2.7'sinde yorgunluk, \%2.5'inde çabuk yorulma ve \%0.3'ünde eforla ilişkili senkop eşlik etmekteydi.

Üçyüzaltmışdört hastanın 44'ünde (\%12.1) aile öyküsü pozitif olarak saptandı. Bunlar içinde; 33'ünde (\%9.1) disritmi öyküsü (2'sine ICD takılmış), 9'unda (\%2.5) ani ölüm öyküsü ve 7'sinde (\%1.9) kardiyak hastalık öyküsü (koroner arter hastalığı, kapak hastalığı, konjenital kalp hastalığı, hipertrofik kmp, aort anevrizması) olduğu öğrenildi. Bu 44 hastanın 4'ünde (\%1.1) EKG'de disritmi, 16'sında (\%4.4) HM'da disritmi saptandı. Holterde disritmi saptanan 16 hastanın 2'sinde (\%0.5) ciddi disritmi mevcuttu ( $\geq \% 10$ VES ve $\geq \% 10$ SVE + VES). Hastalarda aile öyküsünün pozitif olması halinin hem EKG'de hem de holterde disritmi saptanması açısından istatistiksel olarak anlamlı bir fark oluşturmadığı saptandı (p>0.05).

Elektrokardiyografide hastaların \%11.5'inde $(n=42)$ disritmi saptandı. Bu hastaların \%4.7'sinde $(n=17)$ ciddi disritmi bulgusu görüldü. Başvuru EKG'sinde disritmi saptanan hastaların \%6.3'ünde ( $n=23)$ izole çarpıntı ve \%4.1'inde $(n=15)$ çarpıntı ve göğüs ağrısı şikayeti vardı. EKG normal olan 322 hastanın 84'ünde (\%26.1) HM'da disritmi saptandı. Bunlardan 71 hastada (\%84.5) klinik önemsiz disritmi ve 13 hastada (\%15.5) ciddi disritmi mevcuttu. Hem EKG hem de holterde disritmi saptanan 36 hastanın (\%85.7) ise 13'ünde (\%36.1) ciddi disritmi bulgusu saptandı. Hem EKG'de hem de holterde disritmi olan hastalarda EKG'si normal olup holterde disritmi olan hastalara kıyasla ciddi disritmi saptanma oranı anlamlı yüksekti $(p<0.05)$. Elektrokardiyografide disritmi saptanan olgularda HM'da disritmi ve ciddi disritmi saptanması arasında anlamlı korelasyon bulundu $(r=0.4 p<0.0001)$.

Hastaların \%76.4'ünde $(n=278)$ ekokardiyografi normaldi. Patolojik bulgular içinde; \%9.9'u (n=36) MVP ve/veya kapak yetmezliği, \%9.3'ü (n=34) izole kapak yetmezliği (romatizmal, konjenital nedenlere ikincil), \%3.3'ü ( $n=12)$ konjenital kalp hastalığı (10 hasta atrial septal defekt,1 hasta ventriküler septal defekt, 1 hasta patent duktus arteriosus), \%0.8'i ( $n=3)$ diğer patolojiler (sol ventrikül hipertrofisi, septal hipertrofi, koroner arteriyovenöz fistül vb.) ve \%0.3'ü kardiyomiyopati (hipertrofik KMP) yer almaktaydı. Patolojik eko bulguları olan 86 hastanın 5'inde EKG'de ve 28'inde holterde disritmi saptandı. Ekokardiyografi bulguları olan hastalar ile EKG ve HM'da disritmi saptama sıklığı açısından anlamlı fark bulunmadı (p>0.05).

Tablo I: 24 Saatlik Ritim holter analizinde kaydedilen disritmiler.

\begin{tabular}{|c|c|c|}
\hline & \multicolumn{2}{|c|}{ Hastalar $(n=364)$} \\
\hline & $\mathbf{n}$ & $\%$ \\
\hline Supraventriküler ektopiler (izole,<\%10) & 37 & 10.1 \\
\hline Atrial/nodal ektopik atım $>30 /$ saat $(>\% 10)$ & - & - \\
\hline Atrial flutter veya fibrilasyon & 1 & 0.3 \\
\hline Supraventriküler taşikardi & 1 & 0.3 \\
\hline Ventriküler ektopi (izole,<\%10) & 27 & 7.4 \\
\hline Ventriküler ektopik atım >30/saat (>\%10) & 6 & 1.6 \\
\hline Ventriküler bigemine & - & - \\
\hline Supraventriküler ve ventriküler ektopiler & 9 & 2.5 \\
\hline Caupled/tripled atımlar & - & - \\
\hline Ventriküler taşikardi & 3 & 0.8 \\
\hline WPW & 12 & 3.3 \\
\hline AV blok (2 veya 3.derece) & 6 & 1.6 \\
\hline Uzun QT & 1 & 0.3 \\
\hline AV blok (1. derece) & 2 & 0.5 \\
\hline $\begin{array}{l}\text { Sinüs nodu ve atriyum kaynaklı ritimler } \\
\text { (sinus taşikardisi ve bradikardisi, low atrial ritim-düşük atrial ritim, } \\
\text { nodal ritim, wandering atrial pacemaker-değişen atrial pacemaker) }\end{array}$ & 15 & 4.1 \\
\hline
\end{tabular}


Tablo II: Semptom gruplarına göre holterde kaydedilen ritim bozukluğu tipleri ve sıklıkları.

\begin{tabular}{|c|c|c|c|c|c|}
\hline $\begin{array}{c}\text { Ritim Bozukluğu } \\
\text { Tipleri }\end{array}$ & $\begin{array}{c}\text { Grup } 1(\%) \\
\mathrm{n}=206(\% 56.6)\end{array}$ & $\begin{array}{c}\text { Grup 2a (\%) } \\
\mathrm{n}=81(\% 22.3)\end{array}$ & $\begin{array}{c}\text { Grup 2b (\%) } \\
\mathrm{n}=49(\% 13.5)\end{array}$ & $\begin{array}{l}\text { Grup 2c (\%) } \\
\mathrm{n}=28(\% 7.7)\end{array}$ & $\mathbf{P}$ \\
\hline SVE & $21(5.8)$ & $9(2.5)$ & $4(1.1)$ & $3(0.8)$ & 0.959 \\
\hline VES & 19(5.2) & $6(1.6)$ & $7(1.9)$ & $1(0.3)$ & 0.404 \\
\hline SVE+VES & $4(1.1)$ & $3(0.8)$ & $2(0.5)$ & - & 0.575 \\
\hline SVT & $1(0.3)$ & - & - & - & 0.857 \\
\hline VT & $1(0.3)$ & $1(0.3)$ & $1(0.3)$ & - & 0.665 \\
\hline 1. Derece AV Blok & - & $1(0.3)$ & $1(0.3)$ & - & 0.263 \\
\hline 2. Derece AV Blok & $4(1.1)$ & - & - & - & 0.376 \\
\hline 3. Derece AV Blok & $2(0.5)$ & - & - & - & 0.673 \\
\hline Atriyal Flatter & $1(0.3)$ & - & - & - & 0.857 \\
\hline Uzun QT & $1(0.3)$ & - & - & - & 0.857 \\
\hline WPW & $4(1.1)$ & $6(1.6)$ & $1(0.3)$ & $1(0.3)$ & 0.126 \\
\hline $\begin{array}{l}\text { Sinüs nodu ve atriyum } \\
\text { kaynaklı ritimler }\end{array}$ & $10(2.7)$ & $4(1.1)$ & $1(0.3)$ & - & 0.540 \\
\hline $\begin{array}{l}\text { Gruplarda aritmili } \\
\text { hasta toplamı }\end{array}$ & 68 & 30 & 17 & 5 & \\
\hline
\end{tabular}

Grup 1: izole çarpıntı, Grup 2a: çarpıntı ve göğüs ağrısı, Grup 2b: çarpıntı ve baş dönmesi \pm senkop \pm eforla ilişkili senkop, Grup 2c: çarpıntı ve yorgunluk \pm çabuk yorulma \pm nefes darlığı.

Holter monitorizasyon endikasyonları incelendiğinde; önemli bir kısmını kardiyak disritmi düşündüren semptomları devam eden ve nedeni belli olmayan, EKG incelemesi normal olan 322 (\%88.5) hasta olușturmaktaydı. Bunu sırasıyla standart EKG'de disritmi olan 42 hasta (\%11.5), EKO'da MVP ve/veya kapak yetmezliği saptanan 36 hasta (\%9.9), antidisritmik tedavi izlemi alan 16 hasta (\%4.4), pacemaker implantasyonu yapılan 6 hasta (\%1.6) ve kardiyomiyopatisi olan 1 hasta (\%0.3) takip etmekteydi.

Yirmidört saatlik ritim HM kayıtları değerlendirildiğinde 364 hastanın 120'sinde (\%33) disritmi saptandı. Illk HM'da 26 hastada (\%7.1) ciddi disritmi/ klinik açıdan kardiyak önemli disritmiler ve 94 hastada (\%25.9) klinik açıdan önemsiz disritmi kaydedildi. Holterde kaydedilen disritmilerin dağılımı Tablo I'de sunulmuştur. Holterde en sık saptanan ritim bozuklukları \%10.1 ( $n=37$ ) ile SVE ve \%9 ( $n=33$ ) ile VES'di. Bu iki ritim bozukluğunun birlikte görülme oranı \%2.4 $(n=9)$ bulundu. Holter monitorizasyonda SVE saptanan 50 hastanın, 40'ında (\%11) hafif, 1'inde (\%0.3) orta ve 9'unda (\%2.5) ciddi düzeyde SVE saptandl. VES saptanan 45 hastanın, 27'sinde (\%7.4) hafif, 3'ünde (\%0.8) orta ve 15 'inde (\%4.1) ciddi VES mevcuttu. Holterde hastaların \%3.3'ünde $(n=12)$ WPW, \%2.7'sinde $(n=10)$ wandering atriyal pacemaker, \%2.2'sinde $(n=8)$ AV blok (4'ü 2. Derece, 2'si 1. Derece ve 2'si 3. Derece AV blok), $\% 1.9$ 'unda $(n=7)$ sinüs taşikardisi, \%0.8'inde $(n=2)$ sinüzoidal duraklama(<3sn), \%0.8'inde ( $n=3) \mathrm{VT}, \% 0.3$ 'ünde ( $n=1) \mathrm{SVT}$, $\% 0.3$ 'ünde $(n=1)$ nodal ritim, \%0.3'ünde $(n=1)$ așağı atriyal ritim, \%0.3'ünde $(n=1)$ sinüs bradikardisi, \%0.3'ünde $(n=1)$ atrial flatter ve \%0.3'ünde $(n=1)$ uzun QT saptandı. Hastaların HM kayıtlarında hasta sinüs sendromu, sinüzoidal duraklama (>3sn) ve mutifokal/ektopik atrial taşikardi saptanmadı.
Semptom gruplarına göre holterde kaydedilen ritim bozukluğu tipleri ve sıklıkları Tablo Il'de verilmiş̧tir. Tüm gruplarda birlikteliği en sık görülen ritim bozukluğu SVE ve onu takip eden VES idi. SVE + VES'in birlikte görülme oranı gruplar arasında benzerdi. Holterde disritmi görülme sıklığı grup 1 hastalarda grup 2'ye göre daha fazla olmakla birlikte istatistiksel anlamlı fark saptanmadı $(p>0.05)$. Disritmi saptanma sıklığı EKG'de sırasılyla grup 1'de \%6.3 ( $n=23)$, grup 2a'da \%3.8 ( $n=14)$, grup 2b'de \%1.1 ( $n=4)$, grup 2c'de \%0.3 (n=1)'di. Holterde bu oranlar grup 1'de \%18.7 ( $n=68)$, grup 2a'da \%8.3 $(n=30)$, grup 2b'de \%4.6 ( $n=17)$, grup 2c'de \%1.4 ( $\mathrm{n}=5$ ) olarak bulundu. Ciddi disritmi oranları sırasılyla $\% 4.1, \% 0.8$ ve \%1.1 saptandı. Grup 2c'de ciddi disritmi yoktu. Grup 1'de EKG'de disritmisi olan 23 hastadan (\%6.3) 21'inde (\%5.8) holterde disritmi saptanırken, grup 2'de ise 19 hastadan (\%5.2) 15'inde (\%4.1) disritmi saptanmıştır. Fakat iki grup arasında EKG'de disritmi bulgusu olanlarda holterde disritmi saptanma oranları açısından istatistiksel olarak anlamlı fark saptanmadı ( $p>0.05$ ). Çarpıntı yakınması ile başvuran hastalarda EKG'de disritmi bulgusu olanlarda holterde disritmi saptanma oranı anlamlı yüksek bulundu ( $p<0.001)$.

Holter disritmi saptanan 120 hastanın 26'sında (\%7.1) ciddi disritmi saptandı. Bunlar içinde en sık kaydedilenler; 9 hastada (\%2.5) SVE + VES ( $\geq \% 10)$ ve onu takip eden oranda 6 hastada (\%1.7) VES ( $\geq \% 10$ )'di. Grup 1, grup 2a ve 2b'de en sık görülen ciddi disritmi SVE + VES ( $\geq \% 10)$ 'di. Ciddi ritim bozuklukları istatiksel anlamlı fark olmasada izole çarpıntı grubunda (grup 1) diğer gruplara (grup $2 \mathrm{a}, 2 \mathrm{~b}$ ve $2 \mathrm{c}$ ) göre daha yüksek bulunmuştur ( $p>0.05)$.

Çalıșmaya alınan 8 hastaya egzersiz stres EKG testi (efor testi) uygulandı. Bu hastaların holter analizi sonuçları; 2'sinde $\geq \% 10$ VES, 2'sinde <\%10 SVE, 1'inde <\%10 VES ve eforla ilişkili 
Tablo III: Holterde disritmi saptanması açısından belirleyici faktörlerin dağlımı.

\begin{tabular}{|c|c|c|c|c|c|}
\hline \multirow[b]{2}{*}{$\begin{array}{l}\text { Semtom gruplarına göre } \\
\text { (grup 1: izole çarpıntı grup2: eşlik eden } \\
\text { semptomlar) }\end{array}$} & \multirow{2}{*}{$\begin{array}{l}\text { Beta } \\
-0.049\end{array}$} & \multirow{2}{*}{$\begin{array}{c}\text { OR } \\
0.952\end{array}$} & \multicolumn{2}{|c|}{ \%95 Güven Aralığı } & \multirow{2}{*}{$\begin{array}{c}\mathbf{p} \\
0.842\end{array}$} \\
\hline & & & 0.586 & 1.545 & \\
\hline Cinsiyet & -0.043 & 0.958 & 0.569 & 1.613 & 0.872 \\
\hline Ailede disritmi öyküsü & 0.274 & 1.315 & 0.591 & 2.922 & 0.502 \\
\hline EKG Sonucu & 2.885 & 17.899 & 7.219 & 44.378 & 0 \\
\hline $\begin{array}{l}\text { Yaş Grubu } \\
\text { ( } \leq 10 \text { yaş ve } \geq 11 \text { yaş) }\end{array}$ & 0.312 & 1.366 & 0.757 & 2.465 & 0.3 \\
\hline Sabit & -1.278 & 0.279 & & & 0 \\
\hline
\end{tabular}

senkop yakınması, 3'ünde normaldi. Tüm hastalarda VES'lerde baskilanma oldu ve hiçbir hastada eforla disritmi gelişmedi.

Hastaların yaş gruplarına göre ritim bozukluğu incelendiğinde; $\leq 10$ yaş 88 hastada EKG'de disritmi oranı \%3.6, holterde \%7.4 ve ciddi disritmi oranı \%1.1 saptandı. Bu oranlar $\geq 11$ yaş 276 hastada sırasıyla \%8, \%25.5 ve \%6 olarak saptandı. Holterde $\leq 10$ yaş SVE sıklığı \%3 iken, VES sıklığı \%1.4, $\geq 11$ yaş bu oranlar sırasıyla \%7.1 ve \%7.7'di. Holterde disritmi ve ciddi disritmilerin saptanma sıklığı $\geq 11$ yaş grubunda yüksek bulunmasına rağmen yaș ve semptom gruplarına göre istatistiksel olarak fark bulunmadı ( $p>0.05)$.

Holterde disritmiyi saptama açısından belirleyici faktörleri bulmak için yapilan lojistik regresyon analizinde regresyon modeline, hasta grupları ( grup 1 yada 2), cinsiyetleri, ailede disritmi öyküsünün olup olmaması, yaş grubu ( $\leq 10$ yaş ve $\geq 11$ yaş) ve EKG sonucu (normal/disritmi) dahil edildi. Bunun sonuçlarına göre anlamlı tek değişken olarak EKG'de disritmi olması saptandı ve holterde disritmi sonucu elde etme riskini anlamlı arttırdığı bulundu ( $p<0.001$ ) (Tablo III). Holter ve/veya efor testi sonrası hastaların 17'sine medikal tedavi (16's propranolol, 1 'i amiodaron) verildi. Medikal tedaviyle düzelmeyen ve ciddi disritmi bulguları olan 2 hasta elektrofizyolojik çalışma (EPS) için yönlendirildi. 12 WPW hastasında holterde disritmi saptanmadı. Uygun yaş ve kiloda HM normal olan ve çarpıntı yakınması devam eden ( $\geq 6$ yaş) 11 hasta risk analizi için yönlendirildi. Bu hastalardan 2'sinde EPS ile supraventriküler taşikardi atağı tetiklenerek ablasyon tedavisi uygulandı.

\section{TARTIŞMA}

Taşikardi ataklarının kısa süreli ve aralıkı olması, bazen belirtilerin hasta tarafından güçlükle fark edilmesi, hastanın semptomsuz dönemde olması, ritmin kısa bir dönem kaydedilmesi, çocukların rahatsılık geçirdiklerinin farkına varmamaları ve özellikle de çocuk hastaların semptomları tanıyamamaları nedeniyle kendilerini anlatamadıklarından çocukluk çağında rutin EKG'de disritmi saptanması 24 saatlik HM göre yetersiz kalabilmektedir (9-16). Holter analizinde çocuklarda standart
EKG'de saptanamayan ritim bozuklukları, bunların başlangıcı ve süresi değerlendirilebilmektedir (4,5,16-18). Ayrıca semptom sırasındaki EKG kaydı incelenerek bu semptomun kalple ilişkisi belirlenebilmektedir. Tüm bunlar göz önüne alındığında, çocuk yaş grubunda disritmi tanısında en önemli tanı yönteminin HM olduğu açıktır. Çarpıntı ile başvuran pediatrik hastaların \%5.7-35'ine HM ile tanı konulabilmektedir $(9,10)$. Bu nedenle çarpıntı yakınması ile başvuran çocuklarda ritim holter ile değerlendirilmesi değişen klinik bir yaklaşıma sahiptir.

American Collage of Cardiology (ACC) ve American Heart Association (AHH) semptomu olan hastalarda sinif $1 \mathrm{HM}$ endikasyonları içinde; hastada nedeni belli olmayan senkop, presenkop ya da baş dönmesi ataklarının olması ve hastada açıklanmamış, tekrarlayan çarpıntı ataklarının olması yer almaktadır (7). Çalışmamızda HM endikasyonun önemli bir çoğunluğunu \%88.5 ile bu hasta grubu oluşturmaktaydı.

Çarpıntı ve senkop ile başvuran çocuklarda ise ailevi risk faktörü aranmaksızın HM yapılması öneren çalısmalar vardır $(3,12)$. Çalışmamızda 364 hastanın 44'ünde (\%12.1) aile öyküsü pozitif olarak saptandı. Hastalarda aile öyküsünün pozitif olması halinin, EKG'de ve holterde disritmi saptanması açısından istatistiksel olarak anlamlı fark olușturmadığı saptandı ( $p>0.05)$.

Pediatrik yaş grubunda ritim bozukluklarında holter ile ilgili çalışmalar sınırıdır $(6,13)$. Çalışmamızda ise çarpıntı yakınması ile kliniğimize başvuran çocuk hastaların \%33'ünde disritmi saptanmış ve bunların da \%7.1'inde $(n=26)$ ciddi disritmiler olduğu belirlenmiştir. Literatürdeki çalışmalarda, çocuklarda HM'nun \%10.6-61 arasında değișen oranlarda disritmi saptandığı bildirilmektedir (1,6,12). Bununla birlikte çalıșmamızda EKG'si normal olan 322 hastanın \%26.1'inde holterde disritmi kaydedilmesi ritim bozukluklarının saptanmasında çocuk hastlarda EKG'nin yetersiz kalabildiğini ve bu nedenle HM'nun yararı bir tanı aracı olduğunu desteklemektedir.

Yapılan bir çalışmada holter analizi yapılan 402 hastada en sık başvuru yakınması göğüs ağrısı (\%33.6), çarpıntı (\%22.9) ve senkop (\%7) olarak bildirilmiştir (1). Çalışmamızda ise başvuru anında hastaların \%56.9'unda ( $n=206)$ izole çarpıntı ve \%43.4'ünde ( $n=158)$ çarpıntıya eşlik eden yakınmalar; 
bunlar içinde de en sık göğüs ağrısı (\%24.2) ve senkop (\%10.4) saptanmıştır. Hallıoğlu ve ark. (3) çarpıntı, göğüs ağrısı ve senkop gibi disritmik semptomlarla başvuran 4-17 yaş arası 302 hastada 24 saatlik HM'nda; 111 hastada (\%36.7) ritim bozukluğu saptamışlardır. Bu çalışmada çarpıntı ile başvuranlarda disritmi sıklığı \%37.1 (88 hasta), senkop ile başvuranlarda \%39.6 (19 hasta) ve göğüs ağrısı ile başvuranlarda ise \%23.5 (4 hasta) kaydedilmiştir. Buna göre disritmi görülme sıklığı çarpıntı ve senkop ile başvuranlarda göğüs ağrısı ile başvuranlara göre daha fazla olmakla birlikte istatistiksel fark saptamadıklarını bildirmişlerdir. Çalışmamızda holterde disritmi görülme sıklığı \%33'dü. Semptom gruplarına göre holterde disritmi oranları; grup 1'de \%18.7, grup 2a'da \%8.3, grup 2b'de \%4.6 ve grup 2 c'de \%1.4 ile daha düşük oranda bulundu. Semptom grupları arasında ritim bozukluğu açısından anlamlı fark saptanmasa da, izole çarpıntı grubunda diğer gruplara göre daha yüksek oranda disritmi saptanmıştır. Çalışmamızla uyumlu olarak diğer çalışmalarda da yorgunluk, çabuk yorulma ve nefes darlığı yakınmaları olan hastalarda (grup 2c) ciddi bir ritim bozukluğunun saptanmaması bu grup hastalarda HM'nun kullanılabilirliğinin düşük olduğu göstermektedir $(13,16)$.

Binbeşyüz çocuk hastada 2017 holter kaydının değerlendirildiği diğer bir çalsşmada ise en sık kaydedilen disritmiler; SVE, SVT, VES ve AV blok olarak bildirmişlerdir (13). Çalışmamızda ise 364 hastanın HM'nunda en sık \%10.1 ( $n=37)$ ile SVE ve \%9 ( $n=33)$ ile VES saptanmıştır. Bu iki ritim bozukluğunun birlikte görülme oranı ise \%2.4 (n=9) bulunmuştur. Literatürdeki sonuçlarla uyumlu olarak çalışmamızda da çocukluk çağında holterde ventriküler ve supraventriküler ekstra atımlar en sık görülen ritim bozuklukları olarak kaydedilmiştir (Tablo I) (1,3,6,12). Diğer çalsşmalara göre SVT, VT, AV blok gibi klinik önemli disritmilerin çalışmamızda düşük oranda görülmesi; yüksek risk grubunda olan hastaların (opere $\mathrm{KKH}$, kardiyomiyopati vb.) izleminin merkezimizde daha az sıklıkta yapılmasına bağlı olabileceğini düşünmekteyiz. Nitekim yapısal olarak normal olan bir kalpte senkop ve göğüs ağrısı vb semptomlarda holter disritmi kaydedilmesi düşük oranlarda bildirilmiştir (6,19-22). Postoperatif, kardiyomiyopatili veya konjenital kalp hastalığı olanlar disritmi yönünden yüksek riskli gruptadır ve bu olgular asemptomatik bile olsalar erken teşhis ve tedavi için ritim bozuklukları açııından yakın izlenmesi önerilmektedir $(6,23,24)$.

Güven ve ark. (12) çalışmalarında çalışmada asemptomatik ve EKG'de disritmi saptanan olguların \%24'ünde SVT, multifokal VES, kısa VT gibi klinik önemi olan ritim bozuklukları olduğunu göstermişlerdir. Aynı çalısmada eşlik eden EKG bulgusu yoksa hastada klinik olarak önemli ritim bozukluğunun görülme oranının düșük olduğunu bildirmișlerdir (12). Çalıșmamızda hastalardan hem EKG hem de holterde disritmi olan grupta (\%36), EKG normal/holterde disritmi olan gruba göre (\%15) ciddi disritmi saptanma oranı anlamlı yüksek bulundu $(p=0.023)$. Literatürdeki diğer araştırmalarla uyumlu olarak çalışmamızda EKG'de disritmi bulgusunun holterin tanıya katkısının artmasında ve/veya ciddi disritmi saptanmasında belirleyici faktör olarak saptanmıştır $(6,12)$.

Hegazy ve ark.(6) 2000-2006 yılları arası (ortalama yaş $6.7 \pm 4.1$ yıl) 1319 holter kaydını değerlendirdikleri çalışmalarında; en sık holter endikasyonunu çarpıntı ve senkop olarak bulmuşlardır ve 141 hastada (\%10) holterde anormal kayıt saptamışlardır. En sık kaydedilen disritmiler sırasıyla; SVE, VES, SVT, VT, AV blok olarak saptanmıștır. Aynı çalıșmada HM'nun yüksek riskli hasta grubunun (postoperatif ve kardiyomiyopati) değerlendirilmesinde son derece önemli olduğu; senkop, çarpıntı ve göğüs ağrısında tanı değerinin düşük olduğu ve bu hasta grubunda da çalışmamızla uyumlu olarak anormal EKG'nin holter kayıtlarında disritmi saptanması ile anlamlı ilişkisi olduğunu bildirmişlerdir (6).

Disritminin hastanın semptomlarının nedeni olduğu düşünülüyorsa semptom oluştuğunda disritmiyi dökümante etmek oldukça önemlidir $(4,21)$. Porter ve ark.'nı yaptığı bir çalışmada, EKG'leri normal sınılarda olan, çarpıntı, senkop veya baş dönmesi yakınmalarından birisi bulunan 25 çocuk hastanın HM'nda \%12 oranında semptomla eș zamanlı disritmi tespit edilirken, \%36'sında semptom anında disritmi olmadığını göstermişlerdir (21). Kliniğimizde HM sırasında yakınma hisseden 16 hastanın (\%4.4); 6'sında (\%1.6) normal, 6'sında (\%1.6) sinüs taşikardisi, 2'sinde (\%0.5) VT ve 1'inde (\%0.3) $<\% 10$ uniform VES ve 1'inde de (\%0.3) SVT saptanmıştır.

Disritmilerin dağılımı çocukluk çağında yaşa göre farkllık göstermektedir. ÖzellikleVES'lerin görülme sıklığı yaş ile artarken, SVE, SVT ve komplet AV blok daha küçük yaşlarda karşımıza çıkmaktadır $(13,25)$. Çalışmamızda da holter analizinde hemde yaş gruplarına hemde semptom gruplarına göre ritim bozukluğu açısından istatistiksel olarak anlamlı fark saptanmadı ( $p>0.05$ ).

ÇalışmamızdakiSVT \%0.5 ( $\mathrm{n=2}$ ) oranında olup, literatürdeki diğer çalışmalara göre (\%2.1-5.5) daha düşük oranda saptanmıştır $(1,6,12)$. Bunun nedeni hastalarımızın çoğunun çalışma süresince yalnızca bir HM sonucu ile değerlendirilmesine bağlı olabilir. Ayrıca bașka bir merkezde takipte olan bu hastaların bir çoğunun daha önce SVT geçirdiği ve antidisritmik ilaç kullandığı ancak bizim çalışmamıza dahil olan HM analizlerinde normal olduğu görülmüştür. Bu durum tedaviye yanıtın izleminde HM'nun önemi ortaya çıkarmaktadır.

Mitral kapak prolabsusu olan hastalarda özellikle kapak yetmezliği ile birlikte olanlarda potansiyel olarak öldürücü disritmi insidansı genel populasyona göre daha fazladır $(6,26,27)$. Çalışmamızda kapak yetmezliği ile birlikte olan MVP'li hastaların \%3.6'sında ( $n=13)$ holterde disritmi, bunlardan da \%0.8'inde $(n=3)$ ciddi disritmi bulgusu saptandı. İzole MVP'li hastalarda bu oranlar sırasıyla \%2.4 ( $n=9)$ ve \%0.5 ( $n=2)$ 'di. Bu bulgular MVP'li hastaların derecesi ne olursa olsun holter izlemi ile ilgili daha geniş kapsamlı çalışmalara olan intiyacını desteklemektedir.

Çalışmanın retrospektif olması, grup 2a, 2b ve 2c'deki hasta sayılarının az olması bu çalışmanın kısıt|lıklarıdır. Ayrıca 
HM'nun 24 saatlik olması nedeniyle özellikle çarpıntı ve göğüs ağrısı yakınmaları ile gelen hastalarda holterin takılı olduğu 24 saatlik süreçte disritmi gelişmemesi, çocuk hasta tarafından semptomların güçlükle fark edilmesi ve kendilerini anlatamamaları ve hastanın semptomsuz dönemde olması, normal holter sonucunun "sağlıklı grupta" değerlendirilmesine yol açmaktadır.

\section{SONUÇ}

Çalışmamızda hastaların yaklaşık üçte birinde disritmi saptanmış ve bunların da \%7.1'inde $(n=26)$ ciddi disritmiler olduğu belirlenmiştir. Elektrokardiyografide disritmi saptanmasının holter kaydının tanıya katkısını arttırdığı saptanmıştır. Ayrıca EKG'si normal olan hastalarımızda da holterde disritmi kaydedilmesi seyrek olarak çıkan ritim bozukluklarında EKG'nin yetersiz kalabildiğini ve bu nedenle tanı için HM'nun özellikle çocukluk yaş grubunda yararlı bir tanı aracı olabileceğini düşünmekteyiz.

\section{KAYNAKLAR}

1. Kılıç Z, Karataş Z, Uçar B. Çocuklarda Retrospektif Üç Yıllık Holter Monitorizyonu Deneyimi. Yeni Tıp Dergisi 2012;29:95-99.

2. Yiğit F. Ambulatuar Elektrokardiyografik Kayit.Türk Disritmi, Pacemaker ve Elektrofizyoloji Dergisi 2017;5:109-23.

3. Hallığlu O, Giray D, Karpuz D, Özyurt A. Çarpıntı, göğüs ağrısı ve senkop yakınmalı çocuklarda holter monitorizasyon sonuçları: Sekiz yıllık deneyim. Mersin Univ Saglık Bilim Derg 2017;10:82-7.

4. Genç S.. 24 Saatlik Holter EKG Monitorizasyonu Sonuçlarının Retrospektif Kesitsel Değerlendirilmesi, Uzmanlık Tezi. Antalya:2003

5. Harrison DC, Fitzgerald JW, Winkle RA. Ambulatory electrocardiography for diagnosis and treatment of cardiac arrhytmias. N Eng J Med 1976; 294: 373-80.

6. Hegazy RA, Ltfy WN. The value of holter monitoring in the assessment of pediatric patients. Indian Pacing Electrophysiol $\mathrm{J}$ 2007; 7:204-14

7. Blomström-Lundqvist C, Scheinman MM, Aliot EM, Alpert JS, Calkins $\mathrm{H}$, Camm AJ, et al. ACC/AHA/ESC Guidelines for the Management of Patients With Supraventricular Arrhythmias* Executive Summary A Report of the American College of Cardiology/American Heart Association Task Force on Practice Guidelines and the European Society of Cardiology Committee for Practice Guidelines (Writing Committee to Develop Guidelines for the Management of Patients With Supraventricular Arrhythmias). Circulation 2003;108:1871-909.

8. Badri Paudel, Klara Paudel. The Diagnostic Significance of the Holter Monitoring in the Evaluation of Palpitation. J Clin Diagn Res 2013;7:480-3.

9. Wu J, Kessler DK, Chakko S, Kessler KM. A cost-effectiveness strategy for transtelephonic arrhythmia monitoring. Am J Cardio 1995;75:184-5.
10. Kapoor WN, Hammill SC, Gersh BJ. Diagnosis and natural history of syncope and the role of invasive electrophysiologic testing. Am J Cardiol 1989;15:63:730-4.

11. Kennedy HL. The history, science and innovation of Holter technology. Ann Noninvasive Electrocardiol 2006;11:85-94.

12. Güven $H$, Levent $E$, Özyürek $A R$, Büyükinan $M$, Aydoğdu $A$, Parlar A. Çocuklarda 2 Yıllık Holter Monitörizasyon Deneyimi. Ege Tıp Dergisi 2002;41:15-20.

13. Ayabakan C, Ozer S, Celiker A, Ozme S. Analysis of 2017 Holter records in pediatric patients. Turk J Pediatr 2000;4: 286-93.

14. Morita H, Wu J, Zipes DP. The QT syndromes: long and short. Lancet 2008;372:750- 63.

15. Crawford MH,Bernstein SJ,Deedwania PC, DiMarco JP, Ferrick KJ, Garson A Jr, et al. ACC/AHA guidelines for ambulatory electrocardiography: executive summary and recommendations. A report of the American College of Cardiology/American Heart Association task force on practice guidelines (committee to revise the guidelines for ambulatory electrocardiography). Circulation 1999;24:886-93.

16. Steinberg L, Knilans T: Costs and Utility of tests in the evaluation of the pediatric patients with syncope. Prog Pediatr Cardiol 2001;13:139-49.

17. Lown B. Cardiovascular collapse and sudden cardiac death. In: Braunwald E, ed. Heart Disease. A Textbook of Cardiovascular Medicine. Philadelphia: Saunders 1984.p.2.

18. O'Laughlin MP. Syncope in Pediatric Arrhythmias. Garson A, Gilette CP, eds. Electrophysiology and Pacing. 1nd ed. Philadelphia: WB. Saunders, Co 1990;600-16.

19. Geggel RL. Conditions leading to pediatric cardiology concultatiton in a tertiary academic hospital. Pediatrics 2004;114: E409-17.

20. Lawrence PR, Delaney AE. Chest pain in children and adolescents: most causes are benign.Adv Nurse Pract 2004;12:61-6.

21. CJ. Premature atrial contractions and atrial tachyarrhythmias. In: Garson A Jr, Gillette PC, eds. Pediatric arrhythmias: electrophysiology and pacing. WB Saunders 1990; 328-59.

22. Ferriera J, Luis J, Mota P, Anjos R, Meneses I, Bonhorst D, et al. Holter electrocardiography en pediatric cardiology: preliminary experience. Rev Port Cardiol 1996;15:27-33.

23. Fleg JL, Kennedy HL. Long-term prognostic significance of ambulatory electrocardiographic findings in apparently healthy subjects greater than or equal to 60 years of age. Am J Cardiol 1992;70:748-51.

24. Baker RL, Koelling TM. Prognostic value of ambulatory electrocardiography monitoring in patients with dilated cardiomyopathy. J Electrocardiol 2005;38:64-8.

25. Levy AM, Camm AJ, Keane JF. Multiple arrhythmias detected during nocturnal monitoring in patients with congenital complete heart block. Circulation 1977;55:247-53.

26. Krahn AD, Klein GJ, Norris C, Yee R. The etiology of syncope in patients with negative tilt table and electrophysiological testing. Circulation 1995;92:1819-24.

27. Beder S, Cohen M, Riemenschineder T. Occult arrhythmias as the etiology of unexplained syncope in children with structurally normal hearts. Am Heart J 1985;109:309-13. 